\title{
NOTES ON A FEW OF THE RARER NEW ENGLAND LEPIDOPTERA.
}

BY WM. T. M. FORBES, WORCESTER, MASS.

'THese are odds and ends in the way of rarities picked up during several years of collecting. I am indebted to quite a number of entomologists for naming specimens for me, especially to Mr. Busck for naming my Micros.

Anosia plcxippus fumosa; Worcester, fall of 1900 . It was quite common here that year, but I have not seen it once since.

Enptoicta clandia: Wrorcester, Aug., 1900.

Argynnis cybcle: At Crotch Island, near Friendship, Me., the dwarf form almost entirely replaced the usual ones.

Cinelidia harrisii: Worcester.

Basilarchia: 'The majority of astyanax (?) I have caught at W'orcester show traces

of arthemis characters, such as a bit of white band below, or red spots on the hind wing above.

Satyrus alope maritima: Commoner than the type at Friendship, Me.

Chrysophanus hypophlaeas faseiata at Worcester, Westboro, and Fitzwilliam, N. H. " " fulliolus: Worcester, June.

Fenisera tarquinius is certainly not limited by the Connecticut valley. West Swanzey,

N. H., Aug. S, 16; Worcester, July 12; caterpillar webs common at Worcester. Pieris oleracea hiemalis: Slaterville, N. Y.

" " virginiensis: Mt. Killington, I't., not rare.

Oleracea differs not only in looks but in manner of flight from $P$. napi of Europe.

P. rapae immaculata: Amluerst, Mass., May S; Worcester, May 20. Does not seem so common or so well marked as in Europe (Coustantinople).

P. protodice: Worcester, August, 1901.

Eurema lisa: West Swanzey, N. H., Aug. 27, 1903.

Eurymus philodice: A specimen of the spring-brood albino female at Amherst, June 5, Eurymus eurytheme: A typical female (amphidusa) was caught at Seal Harbor, Me., by E. Q. Abbot of Worcester.

Papilio cresphontes: Amherst, Mass.

Lercma hiamna: South Hadley, Mass., on the slope of the Holyoke range.

Eacles imperialis: South Hero, Vt. (eaterpillar.) If what Packard writes is true, this will extend its range the whole length of a state (Monograph of the Bombycine moths, II, 126). 
Anisota senatoria is common at South Hero, I't. (caterpillars).

A pantesis phyllira: Amherst, June 5.

Ammalo tenera: Worcester, July 4.

Estigmane acraea: I have bred a male in which all the white of the wings was slate gray, and the yellow was very dark and dull. 'T'he body is as bright as usual. (var. dubia?)

Estigmene antigone: Paxton, Mass. June.

Diacrisia latipennis: Amherst, June 14; Worcester, June 29.

Phragmatolia assimilans: Worcester, May; found dead under a light.

Panthea furcilla: West Swanzey, N. H., found dead.

Charadra deridens: Amherst, Mass., June 4.

Baileya doubledayi: Amherst, June 13; West Swanzey, Aug. 10.

Adita chionanthi: Amherst, Sept. 22.

Caradrina miranda: Amherst, May 12, 18.

Crambodes talidiformis: Amberst, June 20.

Amolita fessa: Worcester, July $S$ and 10.

Feralia jocosa: Amherst, May 4.

Ufeus satyricus: Amherst, found dead.

Noctua fennica: Worcester, Sept. 12.

Papaipema rigida: Amherst, Sept.

P. inquaesite: Amherst, Sept. 21 to Oct. 12. 'The commonest Gortynid there; both with and without the white spots.

P. impccuniosa: Amberst, Sept. 21.

P. limpida: Amherst, October.

Xylotype capax: Amherst, Oct. 19.

Mamestra congermana: Worcester, July 12.

1I. rubefacta: Amberst, June 12.

Eucalyptera humeralis ? Worcester, June 25 to July 24. Very common and rery fragile.

Erastria albidula: Looks almost exactly like the last on the wing, and flies with it, June 14 to July 27.

Tarache terminimacula: Worcester, July 23.

Salia interpuncta: Found dead in lights at Holyoke, Mass.

Eudeilinea herminiata: Amherst, May 18.

Calledapteryx dryopterata: Amberst, June 19.

Nyctobia limitata: Amherst, April 22.

Phigalia titea; Amherst, May 5. 
A paccasia deductaria: Worcester, Jume 10.

Mctrocampa pracgrandaria: Amherst, June 11; Woreester, Sept 12.

Lagoa crispata: caterpillar common at Amherst.

Thyris maculata: Worcester, July 12.

Blepharomastrix stenialis: Amherst, June 3.

Glyphodes hyalinata: Amherst, Oct. 4.

Loxostege olliteralis: Worcester, June 2S, July 24.

L. extricalis: Worcester, June 8 .

Phlyetaenia tertialis: Amherst, Jume 2, 4.

Pyrausta aeglealis: Amherst, Jume 11.

P. theseusalis: Wrorcester, June 13.

Nymphula badiusalis: Westborough, July 19, common at Hockomocko pond.

Schaonobius unipunctcllus: ITorcester, July 19.

Pcoria hacmatella: Worcester, June 16 to July 4.

Oxiptilus temidactylus: Woreester, July 30.

marginidactyla: Worcester, June 21.

Pterophorus brucei: Worcester, July 5.

P. elliottii: Woreester, common early in July.

\section{CHERMES OF MIAINE SPRUCES.}

BY EDITH M. PATCH, ORONO, MANE.

Six species of gall forming Chermes have been under observation on spruees in the vicinity of Orono during the season of 1909.

1. Chermes pinifoliae Fitch. This dark species develops in a eone-like gall on the black and red spruce (in which connection it was named abicticolens in 1879 by 'Thomas and subsequently merged by error with abietis in 1897) and migrates to the needles of the white pine to oviposit (in which connection it had been previously named pinifolice by Fitch in 1S58, and merged by error with pinicorticis in 1S69). A historieal diseussion with full reasons for resurrecting this doubly merged species under the original name of pinifoliae, which has been discarted for about 40 years, will be published presently together with a technical deseription of the species, by the Maine Agrieultural Experiment Station. 

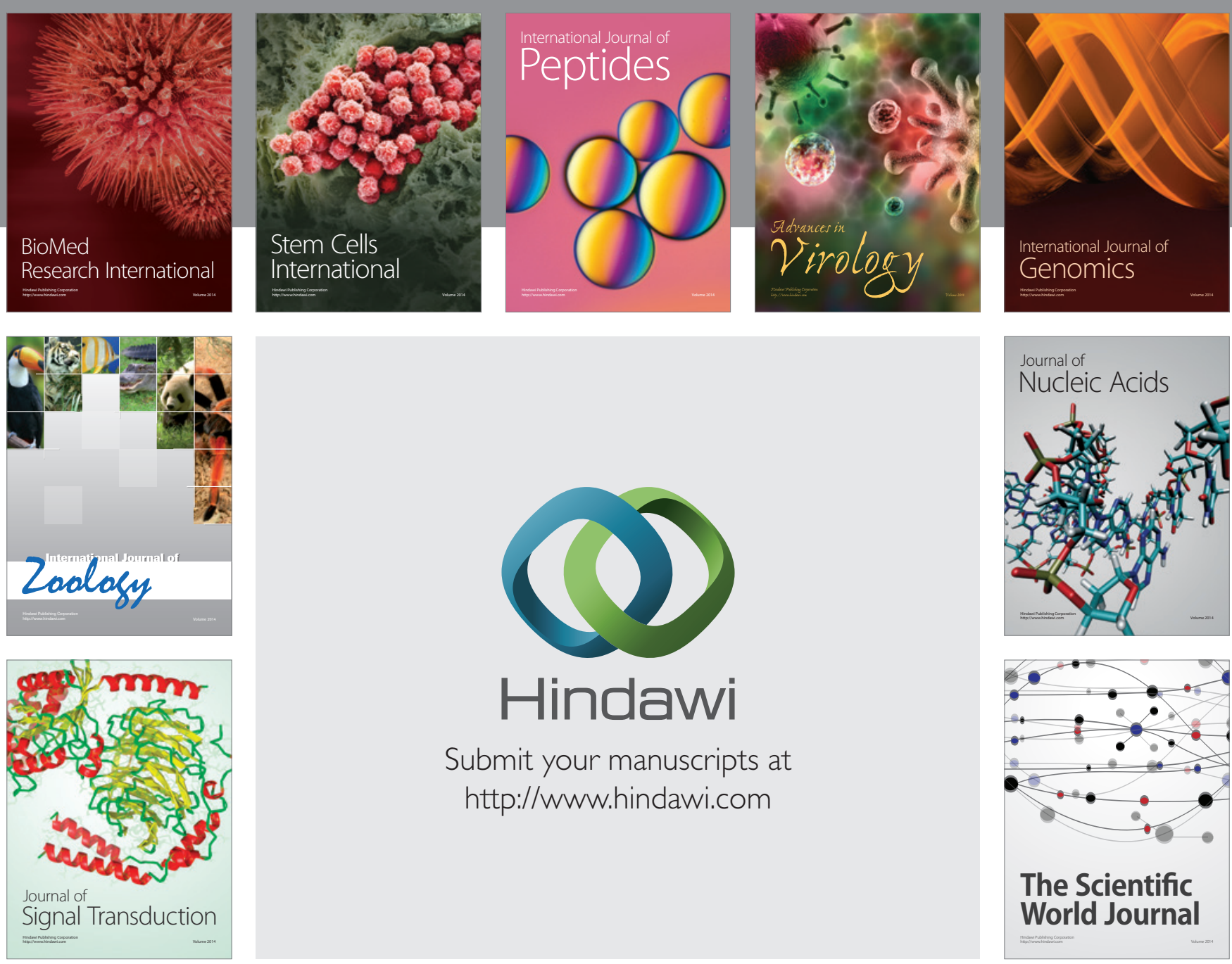

Submit your manuscripts at

http://www.hindawi.com
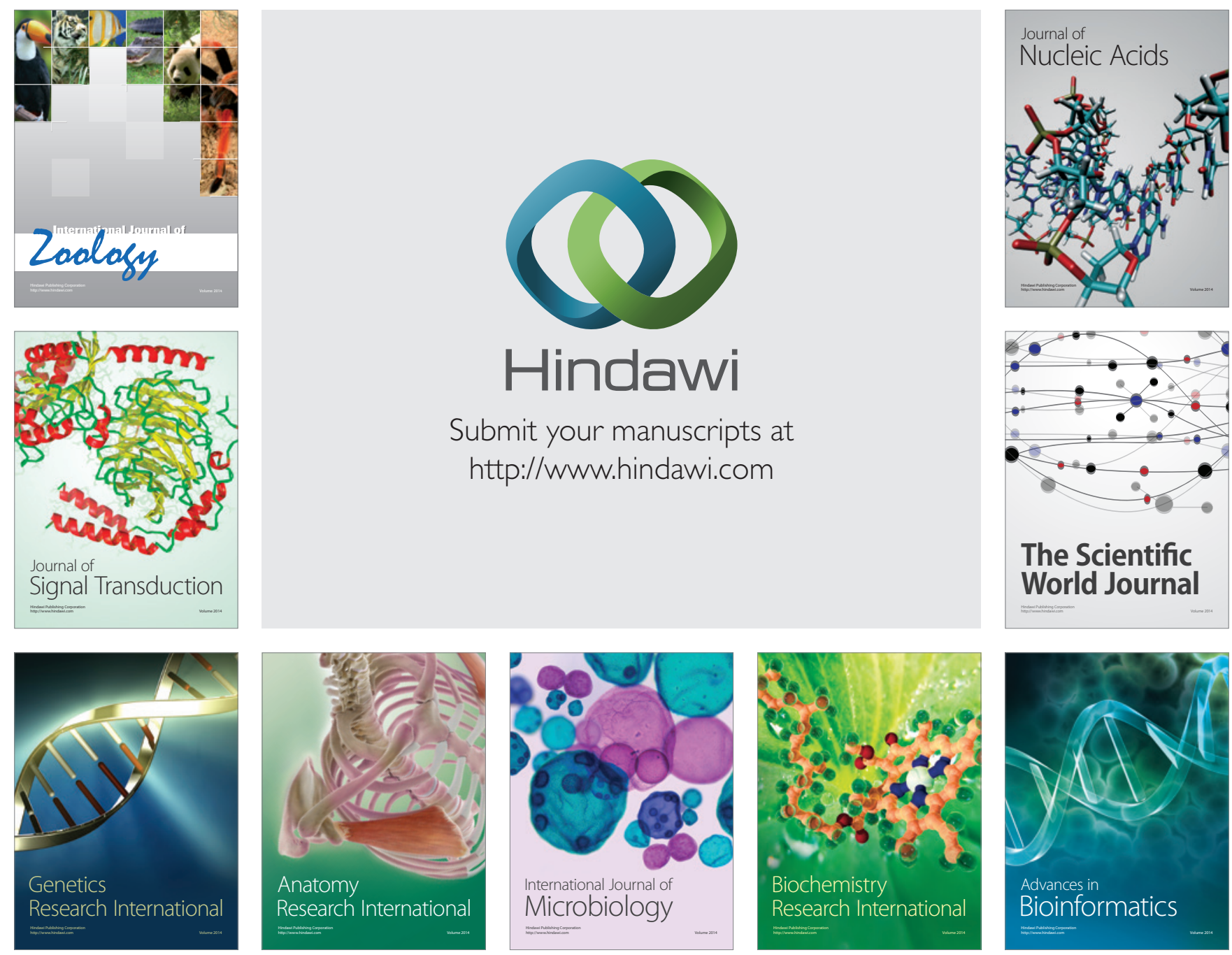

The Scientific World Journal
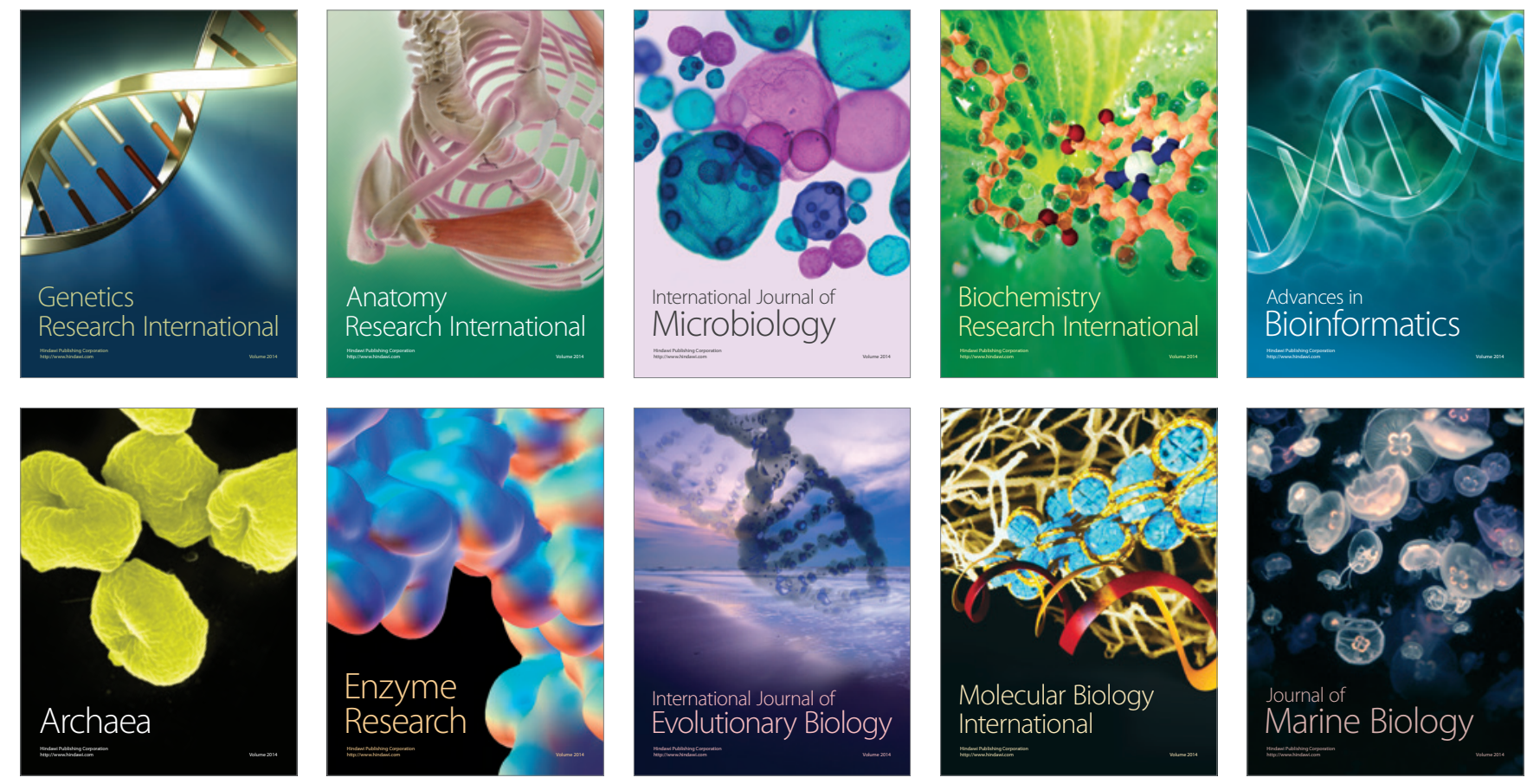